\title{
Nymph developmental time and survivorship, adult longevity, reproduction and body weight of Dichelops melacanthus (Dallas) feeding on natural and artificial diets
}

\author{
Antônio R. Panizzi ${ }^{1}$, Leandro J. S. Duo², Nágila M. Bortolato³ \& Fábio Siqueira ${ }^{4}$
}

\begin{abstract}
${ }^{1}$ Laboratório de Bioecologia de Percevejos, Embrapa Soja, Caixa postal 231, 86001-970 Londrina-PR. panizzi@cnpso.embrapa.br ${ }^{2}$ Departamento de Química, Universidade Estadual de Londrina, Caixa postal 6001, 86051-970 Londrina-PR.

${ }^{3}$ Departamento de Biologia, Universidade Filadélfia de Londrina, Avenida JK 1626, 86020-000 Londrina, PR.

${ }^{4}$ Departamento de Zoologia, Universidade Federal do Paraná, Caixa postal 19020, 81531-990 Curitiba, PR.
\end{abstract}

\begin{abstract}
Nymph developmental time and survivorship, adult longevity, reproduction and body weight of Dichelops melacanthus (Dallas) feeding on natural and artificial diets. The biology of nymphs and adults of the neotropical pentatomid, Dichelops melacanthus (Dallas), feeding on the natural foods, soybean, Glycine max (L.) Merrill immature pods, and corn, Zea mays L. immature seeds, and on an artificial dry diet, was studied in the laboratory. Nymph developmental time was shorter on the natural foods (ca. 21-22 days) than on the artificial diet (28 days), and most nymphs reached adulthood on the food plants (55\% on soybean and $73 \%$ on corn) than on the artificial diet $(40 \%)$. Fresh body weight at adult emergence was similar and higher for females raised as nymphs on the natural foods, compared to females from nymphs raised on the artificial diet; for males, weights were similar on all foods. Mean (female and male) survivorship up to day 20 , decreased from $55 \%$ on soybean to $40 \%$ on corn, down to $0 \%$ on the artificial diet. Total longevity for females was higher on soybean, while for males was similar on all foods. About three times more females oviposited on soybean than on corn, but fecundity/female was similar on both foods. On the artificial diet, only one out of 30 females oviposited. Fresh body weight of adults increased significantly during the first week of adult life, and at the end of the $3^{\text {rd }}$ week, weight gain was similar on all foods.
\end{abstract}

KEYWORDS. Biology; food; Heteroptera; Insecta; Pentatomidae.

RESUMO. Sobrevivência e tempo de desenvolvimento ninfal, reprodução e peso do corpo de Dichelops melacanthus (Dallas) alimentados com dieta natural e artificial. A biologia de ninfas e de adultos do pentatomídeo neotropical Dichelops melacanthus (Dallas), alimentando-se de vagens imaturas de soja, Glycine max (L.) Merrill e sementes imaturas de milho, Zea mays L., e de dieta artificial seca, foi estudada em laboratório. O tempo de desenvolvimento ninfal foi menor nas dietas naturais (ca. 21-22 dias) do que na dieta artificial (28 dias), e a maioria das ninfas atingiram a fase adulta nas dietas naturais (55\% em soja e $73 \%$ em milho) o que não ocorreu na dieta artificial (40\%). O peso fresco dos adultos na emergência foi semelhante e maior para as fêmeas criadas como ninfas nas dietas naturais, comparado às fêmeas cujas ninfas foram criadas na dieta artificial; para os machos, os pesos foram semelhantes em todos os alimentos. A sobrevivência média de fêmeas e machos no $20^{\circ}$ dia decresceu de $55 \%$ em soja para $40 \%$ em milho, e para $0 \%$ na dieta artificial. A longevidade total para fêmeas foi maior em soja, enquanto para machos foi semelhante em todos os alimentos. Cerca de três vêzes mais fêmeas ovipositaram em soja do que em milho, mas a fecundidade/fêmea foi semelhante em ambos os alimentos. Na dieta artificial, de 30 fêmeas, apenas uma ovipositou. O ganho de peso fresco de adultos aumentou significativamente na primeira semana de vida adulta; no final da $3^{\mathrm{a}}$ semana, o ganho de peso foi semelhante em todos os alimentos.

PALAVRAS-CHAVE. Alimento; biologia; Heteroptera; Insecta; Pentatomidae.

The neotropical pentatomid Dichelops melacanthus (Dallas) is an important pest of several crops in southern Brazil. It was previously recorded feeding and damaging young corn plants (Zea mays L.), and because of its damage, chemical control measures were recommended to prevent economic losses to this crop (Ávila \& Panizzi 1995, Gomez 1998).

D. melacanthus is also reported as a minor pest of soybean [Glycine max (L.) Merrill] (Galileo et al. 1977), along with another species of the same genus, D. furcatus (F.), which is often referred to as a secondary soybean pest (Galileo et al. 1977, Panizzi \& Corrêa-Ferreira 1997). Because the two species are similar in appearance (Grazia 1978) it is likely that many of the reports on these species feeding either on soybean or corn contain misidentification of the species. More recently,
D. melacanthus has been reported as a pest of wheat (Triticum aestivum $\mathrm{L}$.) causing economic damage, at least in some areas in the north of Paraná state (Chocorosqui \& Panizzi 2004, Manfredi-Coimbra et al. 2005).

One reason to explain the dramatic increase in numbers of D. melacanthus is the massive adoption by growers of the notillage cultivation system in southern Brazil that was proved to favor the biology of this stink bug which is commonly found on undisturbed soil underneath debris (Chocorosqui \& Panizzi 2004). Also, the cultivation of host plants such as soybean, corn and wheat in sequence on most areas of this region is helping the build up of populations of the bug.

In this paper we report results of laboratory studies in which nymphs and adults of $D$. melacanthus were reared on 
two of their natural foods, i.e., soybean (immature pods) and corn (immature seeds), and on an artificial dry diet, which has been tested for other species of pentatomids (Panizzi et al. 2000, Fortes et al. 2006).

\section{MATERIALAND METHODS}

Nymphal Study. During November-December 2005, adults of D. melacanthus were collected at the Embrapa (Empresa Brasileira de Pesquisa Agropecuária) Farm in Londrina Co., northern Paraná State, from areas under no-tillage that were cultivated with wheat/corn in the previous winter/spring. In general, bugs were found on the soil, underneath debris. They were taken to the laboratory and placed in a clear plastic box $(25 \times 20 \times 20 \mathrm{~cm})$, and they were provided with mature seeds of soybean, raw shelled peanuts (Arachis hypogaea L.) and fruits (berries) of privet, Ligustrum lucidum Ait. (Oleaceae). Bugs were fed fruits of privet because they are known to increase the fecundity of pentatomids (Panizzi et al. 1996, Panizzi \& Mourão 1999, Coombs 2004). Eggs were collected daily. On the first day of the second instar (first instars stay in group and do not feed), 60 nymphs were place singly in $9.0 \times 1.5 \mathrm{~cm}$ Petri dishes with moistened filter paper, and were fed immature soybean pods (cv. BR-267); 60 nymphs were fed immature seeds of corn (cultivar unknown); and 60 nymphs were fed pieces $\left(\mathrm{H}^{\prime} 0.5 \mathrm{~cm}^{3}\right)$ of the dry artificial diet (Table I). Diet components were mixed, spread over a plastic lid lined with aluminum foil, cut in pieces and dried at $80{ }^{\circ} \mathrm{C}$ for 6 hours (Panizzi et al. 2000). In this last food, wet cotton was offered to provide water. The food and filter paper in each Petri dish were changed every 2 days.

The dishes were placed at random in an environmental chamber maintained at $25 \pm 1{ }^{\circ} \mathrm{C}$ and $65 \pm 5 \% \mathrm{RH}$ and with a photoperiod of 16:08 (L:D). Daily observations were made on molting and mortality. Nymphal developmental time and percentage of mortality of each instar, and from 2 nd instar to
Table I. Dry artificial diet tested for rearing Dichelops melacanthus in the laboratory.

\begin{tabular}{lc}
\hline \multicolumn{1}{c}{ Components } & Amounts \\
\hline Wheat germ & $17.9 \mathrm{~g}$ \\
Soybean protein & $15.0 \mathrm{~g}$ \\
Dextrose & $7.5 \mathrm{~g}$ \\
Potato starch & $7.5 \mathrm{~g}$ \\
Sucrose & $2.5 \mathrm{~g}$ \\
Cellulose & $12.5 \mathrm{~g}$ \\
Soybean Oil & $20.0 \mathrm{ml}$ \\
Vitamin Solution $^{1}$ & $5.0 \mathrm{ml}$ \\
Water $^{1}$ & $30.0 \mathrm{ml}$ \\
\hline
\end{tabular}

${ }^{1}$ Vitamin solution composition: niacinamide $1 \mathrm{~g}$, calcium pantothenate $1 \mathrm{~g}$, thiamine $0.25 \mathrm{~g}$, riboflavin $0.5 \mathrm{~g}$, pyridoxine $0.25 \mathrm{~g}$, folic acid 0.25 $\mathrm{g}$, biotin $0.02 \mathrm{ml}$, vitamin $\mathrm{B}_{12} 1 \mathrm{~g}$, added into $1000 \mathrm{ml}$ of distilled water.

adult, were calculated. Fresh body weight at adult emergence was taken using an electronic balance. Data were submitted to analysis of variance (ANOVA), Tukey's and $t$ test $(\mathrm{P}<0.05)$ (SAS Institute 1981, Zar 1984).

Adult Study. Adults were obtained from additional nymphs reared in the laboratory, as described above. On the day of emergence, 30 single female/male pairs were each placed in a plastic rearing box $(12 \times 12 \times 3.8 \mathrm{~cm})$ with moistened filter paper and the box was covered with a lid. Food and water were provided as described for the nymphal study. A dry absorbent cotton ball (H" $5 \mathrm{~cm}$ diameter) was added to each box to serve as substrate for egg deposition, which has been very suitable to receive eggs of several species of pentatomids, including D. melacanthus (Silva \& Panizzi 2007). Adult performance was assessed for each of the 30 pairs. Food was replaced every 2 days. During March-April, 2006, daily observations were made on adult survivorship and reproduction. Survivorship up to day 20 , total longevity, percentage of females ovipositing, mean

Table II. Mean ( \pm SEM) developmental time and mortality of Dichelops melacanthus feeding on cultivated host plants and on artificial dry diet in the laboratory.

\begin{tabular}{|c|c|c|c|c|c|c|c|}
\hline \multirow{2}{*}{$\begin{array}{c}\text { Foods } \\
\left.\text { [initial \# nymphs }{ }^{3}\right]\end{array}$} & \multicolumn{4}{|c|}{ Stadium duration (days) ${ }^{1}$} & \multicolumn{2}{|c|}{ Total developmental time (days) $)^{1,2}$} & \multirow{2}{*}{$\begin{array}{c}\% \text { Total } \\
\text { Mortality }\end{array}$} \\
\hline & Second & Third & Fourth & Fifth & Female & Male & \\
\hline $\begin{array}{l}\text { Soybean, } \\
\text { immature pod } \\
{[60]}\end{array}$ & $\begin{array}{c}5.4 \mathrm{~b} \\
( \pm 0.23) \\
{[46]}\end{array}$ & $\begin{array}{c}4.7 \mathrm{~b} \\
( \pm 0.12) \\
{[43]}\end{array}$ & $\begin{array}{c}4.5 \mathrm{~b} \\
( \pm 0.16) \\
{[40]}\end{array}$ & $\begin{array}{c}7.0 \mathrm{~b} \\
( \pm 0.19) \\
{[33]}\end{array}$ & $\begin{array}{c}20.8 \mathrm{~b} \\
( \pm 0.53) \\
{[18]}\end{array}$ & $\begin{array}{c}21.6 \mathrm{~b} \\
( \pm 0.62) \\
{[15]}\end{array}$ & 45.0 \\
\hline $\begin{array}{l}\text { Corn, immature } \\
\text { seed } \\
{[60]}\end{array}$ & $\begin{array}{c}5.2 \mathrm{~b} \\
( \pm 0.15) \\
{[56]}\end{array}$ & $\begin{array}{c}4.4 \mathrm{~b} \\
( \pm 0.12) \\
{[50]}\end{array}$ & $\begin{array}{c}5.0 \mathrm{~b} \\
( \pm 0.17) \\
{[46]}\end{array}$ & $\begin{array}{c}7.3 \mathrm{~b} \\
( \pm 0.18) \\
{[44]}\end{array}$ & $\begin{array}{c}22.1 \mathrm{~b} \\
( \pm 0.45) \\
{[20]}\end{array}$ & $\begin{array}{c}21.8 \mathrm{~b} \\
( \pm 0.44) \\
{[24]}\end{array}$ & 26.7 \\
\hline $\begin{array}{l}\text { Artificial diet } \\
{[60]}\end{array}$ & $\begin{array}{c}6.5 \mathrm{a} \\
( \pm 0.32) \\
{[47]}\end{array}$ & $\begin{array}{c}7.6 \mathrm{a} \\
( \pm 0.36) \\
{[45]}\end{array}$ & $\begin{array}{c}8.0 \mathrm{a} \\
( \pm 0.46) \\
{[35]}\end{array}$ & $\begin{array}{c}8.7 \mathrm{a} \\
( \pm 0.34) \\
{[22]}\end{array}$ & $\begin{array}{c}28.1 \mathrm{a} \\
( \pm 0.96) \\
{[10]}\end{array}$ & $\begin{array}{c}28.0 \mathrm{a} \\
( \pm 1.21) \\
{[12]}\end{array}$ & 60.0 \\
\hline
\end{tabular}

${ }^{1}$ Means in each column followed by the same letter are not significantly different $(\mathrm{P}<0.05$; Tukey test).

${ }^{2}$ From second stadium to adult.

${ }^{3}$ Numbers surviving each stadium are given. 


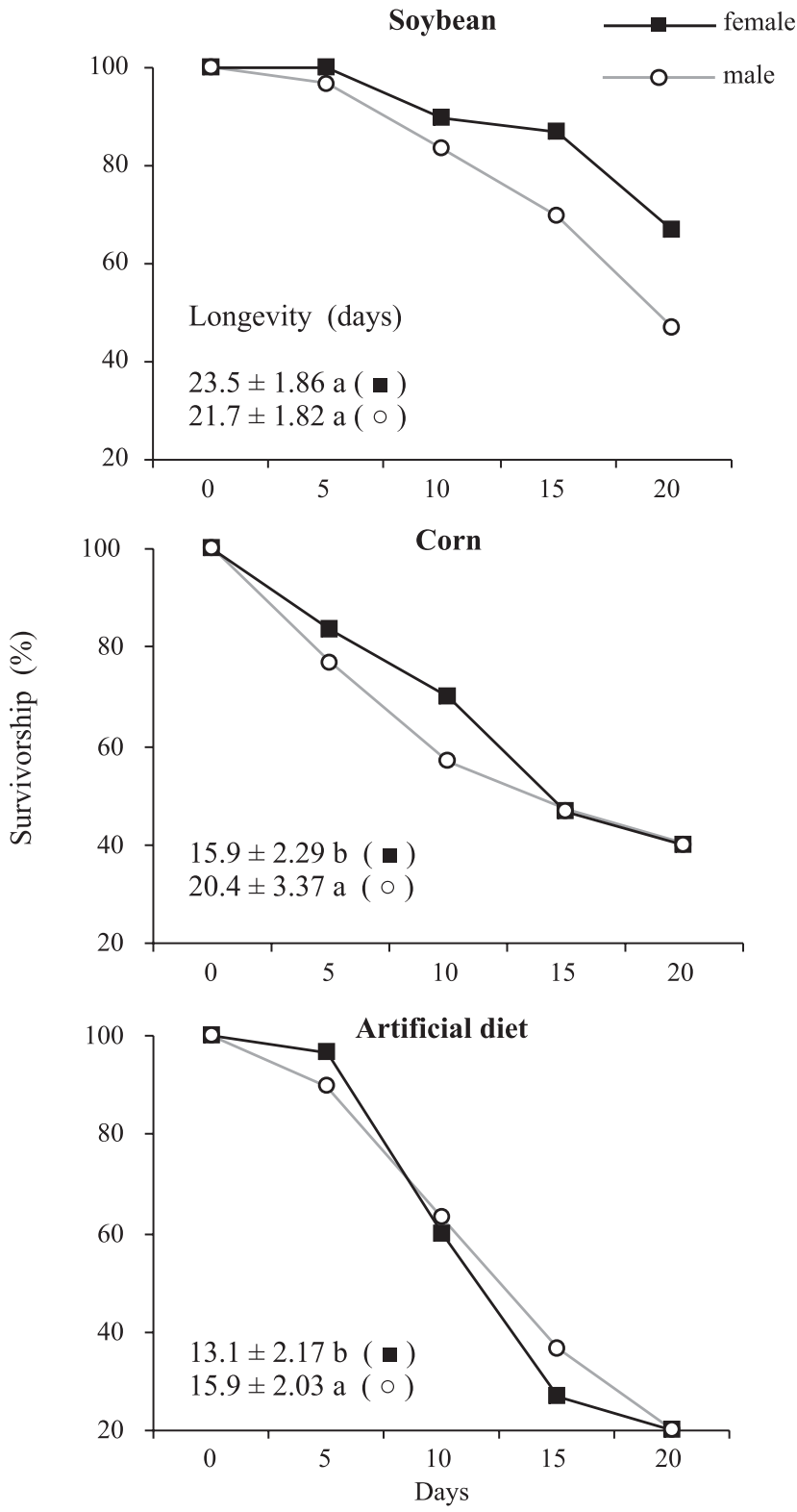

Fig. 1. Survivorship (\%) up to 20 days and longevity (mean \pm SEM) of adult Dichelops melacanthus feeding on natural (immature pods of soybean and immature seeds of corn), and on artificial dry diet in the laboratory. Means (between foods for each gender) followed by the same letter do not differ significantly $(\mathrm{P}<0.05)$ using the Tukey test.

number of egg masses and eggs per female, and percentage of egg hatch were calculated. Adult body weights at emergence and weekly up to the 3 rd week after emergence were measured. Data were analyzed with ANOVA, Tukey's, and $t$ test $(\mathrm{P}<0.05)$ (SAS Institute 1981, Zar 1984).

\section{RESULTS ANDDISCUSSION}

Nymphal Survivorship. Survivorship of D. melacanthus nymphs was variable on the different foods utilized. The smallest mortality occurred on immature seeds of corn, followed by immature pods of soybean with an intermediate value, and on the artificial diet with the highest value (Table II).

Although bugs do not feed on corn ears or seeds in the field, but rather feed on young plants, nymphs survived better on immature seeds of corn than on the other natural food, soybean pods. On this last food, our data (45\%) is very similar to the $44 \%$ nymphal mortality reported by Chocorosqui \& Panizzi (2002), and identical to the mean mortality obtained for nymphs reared on four different photoperiodic regimes and fed pods (immature) and seeds (mature) of soybean (Chocorosqui \& Panizzi 2003). The mortality of nymphs on the artificial diet (60\%) was higher than that observed for other species of stink bugs such as Nezara viridula (L.) $(28.7-38.4 \%$ - Panizzi et al. 2000; 24.0-30.4\% - Fortes et al. 2006; 5.0-12.5\% - Noda \& Kamano 2002), Euschistus heros (F.) (18.4-35.9\% Fortes et al. 2006), and Nezara antennata Scott (30\% - Noda \& Kamano 2002), reared on diets similar to the one we used. This result might be due to slight differences in the components of the various artificial diets used by different authors and to the characteristics of $D$. melacanthus that did not adapt to the diet as well as the other species of stink bugs. However, the $40 \%$ survivorship of nymphs cannot be considered negligible, since this type of result may occur even with the use of preferred food plants (Panizzi \& Alves 1993).

Nymphal Developmental Time. The time required by $D$. melacanthus nymphs to reach adulthood (considering from the $2^{\text {nd }}$ instar to adult, since the bugs do not feed during the $1^{\text {st }}$ instar) was longer for the bugs fed the artificial diet (ca. 28 days) compared to the bugs fed the natural foods (20.8 to 22.1 days) (Table II). This delay of 6 to 8 days on the artificial compared to the natural diets again demonstrates that the first food is not perfectly suitable. Our data obtained on the natural foods (i.e., soybean and corn, immature pods and seeds, respectively) are comparable to those obtained with soybean (immature pods + mature seeds) under similar conditions of temperature and light regimes (24.0 days - Chocorosqui \& Panizzi 2002; 20.8 days - mean obtained for bugs reared under 13 and 14 hours of photophase - Chocorosqui \& Panizzi 2003).

Table III. Mean $( \pm$ SEM) fresh body weight of Dichelops melacanthus at adult emergence feeding on cultivated host plants and on artificial dry diet in the laboratory.

\begin{tabular}{lcc}
\hline \multirow{2}{*}{ Food } & \multicolumn{2}{c}{ Fresh body weight $^{1}$} \\
& Female & Male \\
\cline { 2 - 3 } & 51.2 a A & 41.1 a B \\
Soybean, immature pod & $( \pm 1.63)[18]$ & $( \pm 1.17)[15]$ \\
& 47.2 a A & 41.8 a B \\
Corn, immature seed & $( \pm 1.65)[20]$ & $( \pm 1.01)[24]$ \\
& 43.9 b A & 42.8 a A \\
Artificial diet & $( \pm 1.43)[10]$ & $( \pm 1.51)[12]$ \\
\hline
\end{tabular}

${ }^{1}$ Means followed by the same lowercase letter in each column and uppercase letter in each row do not differ significantly $(\mathrm{P}<0.05)$ using Tukey and $t$ test, respectively. Number of adults in brackets. 
Although nymph developmental time varies according to the light and temperature regimes and food used, clearly the artificial diet abnormally delayed development. This can be noticed from the very beginning of nymph development through the different nymphal stadia (Table II).

Body Weight at Adult Emergence. Fresh body weight at adult emergence was also variable according to the food taken by nymphs (Table III). On the natural diets, D. melacanthus females and males showed similar weights on soybean (ca. 51 and $41 \mathrm{mg}$, respectively) and on corn (ca. 47 and $42 \mathrm{mg}$ ). However, females were heavier than males on both foods. On the artificial diet, body weight of females was significantly reduced (ca. $44 \mathrm{mg}$ ), while for males it was comparable to those of bugs fed on natural diets. These results on the natural foods are comparable to those previously reported by Chocorosqui \& Panizzi (2003) (ca. 51 and 46 mg, for females and males, respectively).

Adult Survivorship and Longevity. Adult survivorship up to 20 days of life gradually decreased on all foods. On soybean, females started do die from day 5 to day 10 , and at day 20,65\% of females were alive; males showed a similar pattern of survivorship, however, mortality was higher, with less than half of males still alive at day 20 (45\%) (Fig. I). On corn, survivorship of both, females and males, decreased on a sharper pattern down to $40 \%$ at the end of day 20 . On the artificial diet, survivorship decreased even faster, most adults died after 15 days, and none reached day 20. Total mean longevity was significantly greater for females on soybean than on corn or on the artificial diet, while for males no significant differences were observed, only a tendency of lower longevity on corn and on the artificial diet (Fig. I). No data was found in the literature regarding the total longevity of D. melacanthus on any food. However, our data showing a mean longevity (females + males) of ca. 22 days on the best food (soybean), suggest that none of the foods tested are suitable. Usually, phytophagous pentatomids live longer than that (see references in Panizzi 2007). Also, the fact that $D$.

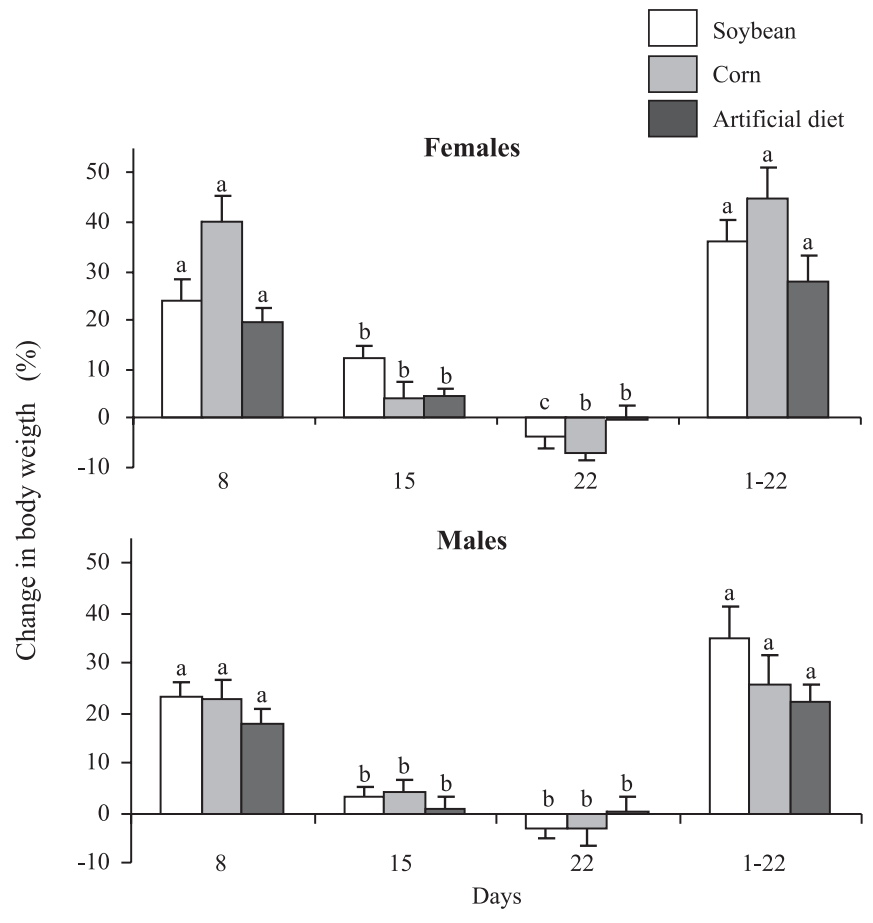

Fig. 2. Mean $( \pm$ SEM) percentage change in fresh body weight during the first three weeks of adult life and from day 1 to day 22 of Dichelops melacanthus feeding on natural (immature pods of soybean and immature seeds of corn), and on artificial dry diet in the laboratory. Means for each diet among weeks, and for each diet during the whole period (day 1 to day 22) followed by the same letter do not differ significantly ( $P$ $<0.05)$ using the Tukey test. Data transformed to arcsine for analysis.

melacanthus is not a major pest of soybean and does colonize corn plants, despite their heavy damage to corn seedlings (Chocorosqui \& Panizzi 2003), reinforce the suspicion of the unsuitability of the foods tested. In addition, the habit of $D$. melacanthus living on the ground on undisturbed soil with crop residues including dropped seeds of soybean and wheat and their respectively seedlings (Chocorosqui \& Panizzi 2004) point to the need of a mixed diet.

Table IV. Reproductive performance of females Dichelops melacanthus feeding on natural diets (immature pods of soybean and immature seeds of corn) and on artificial dry diet in the laboratory.

\begin{tabular}{|c|c|c|c|c|}
\hline \multirow[b]{2}{*}{ Foods } & \multirow{2}{*}{$\begin{array}{l}\text { \% Females } \\
\text { Ovipositing }\end{array}$} & \multicolumn{2}{|c|}{$\mathrm{N}^{\mathrm{o}} /$ females $^{1}$} & \multirow{2}{*}{$\begin{array}{c}\% \text { Egg } \\
\text { hatch }^{1,2}\end{array}$} \\
\hline & & Egg masses & Eggs & \\
\hline $\begin{array}{l}\text { Soybean, immature pod } \\
(30)\end{array}$ & $\begin{array}{l}63.3 \\
(19)\end{array}$ & $\begin{array}{c}3.6 \pm 0.43 \mathrm{a} \\
(19)\end{array}$ & $\begin{array}{c}35.9 \pm 5.45 \mathrm{a} \\
(19)\end{array}$ & $\begin{array}{c}50.3 \pm 8.10 \mathrm{a} \\
(19)\end{array}$ \\
\hline $\begin{array}{l}\text { Corn, immature seed } \\
(30)\end{array}$ & $\begin{array}{c}23.3 \\
(7)\end{array}$ & $\begin{array}{c}3.4 \pm 0.84 a \\
(7)\end{array}$ & $\begin{array}{c}40.4 \pm 11.98 \mathrm{a} \\
(7)\end{array}$ & $\begin{array}{c}47.0 \pm 16.64 \mathrm{a} \\
(7)\end{array}$ \\
\hline $\begin{array}{l}\text { Artificial diet }{ }^{3} \\
\text { (30) }\end{array}$ & $\begin{array}{l}3.3 \\
(1)\end{array}$ & $\begin{array}{l}4.0 \\
(1)\end{array}$ & $\begin{array}{l}48.0 \\
(1)\end{array}$ & $\begin{array}{l}83.3 \\
(1)\end{array}$ \\
\hline
\end{tabular}

${ }^{1}$ Means $( \pm$ SEM) followed by the same letter in each column, do not differ significantly using $t$ test $(\mathrm{P}<0.05)$.

${ }^{2}$ Data were transformed to arcsine for analysis.

${ }^{3}$ No statistics were used to compare the data because only one female oviposited. 
Adult Reproduction. The percentage of females that oviposited varied from ca. $63 \%$ on soybean, decreased to ca. $23 \%$ on corn, and went down to ca. $3 \%$ on the artificial diet (Table IV). The total number of egg masses and eggs/female was similar for those fed the natural diets (mean of ca. 3.5 and 38.0 , respectively). Egg hatchability reached only ca. $50 \%$ of the total eggs. The only one female that oviposited when fed the artificial diet, showed a similar fecundity, higher egg hatchability, but this single data was not included in the statistical analysis. Our data is pretty much in accordance to what was reported by Chocorosqui \& Panizzi (2003) for females fed on soybean pods under 14 hours photophase: $65 \%$ of females oviposited and 55\% egg hatchability, however, they found greater fecundity (7.9 and $55.8 \mathrm{egg}$ masses and eggs/ female, respectively) than here reported.

Adult Body Weight. Fresh body weight gain occurred mostly during the first week of adult life on all three foods, and to a lesser degree during the second week; during the third week both females and males lost weigh or did not gain any weight (Fig. II). Considering the total period of three weeks, body weight of females and males increased on all foods, despite the clear tendency of more weight gain on the natural diets. The tendency of less body weight gain for females on the artificial diet was certainly due to the lack of ovary development, which prevented the typical abdominal size increase of mature females.

In conclusion, known to inhabit soybean and corn fields, D. melacanthus nymphs and adults survived and reproduced relatively well when fed on immature pods and seeds of these two food plants. Although allowing a substantial amount of nymphs to reach adulthood, the artificial diet did not promote adult reproduction, as previously reported to other species of pentatomids (Panizzi et al. 2000, Fortes et al. 2006). Clearly, more studies are needed to adjust the diet to the adult biology of stinkbugs.

Acknowledgments. We thank Edson Hirose (UNICENTRO), D.R. Sosa-Gomez, B.S. Corrêa-Ferreira (Embrapa Soja) and two anonymous reviewers for critical reading the manuscript. This study was sponsored by the Empresa Brasileira de Pesquisa Agropecuária (Embrapa). LJSD, NMB, and FS were supported by scholarships granted by Embrapa, Pioneer Co., and CAPES, respectively. This paper was approved for publication by the Editorial Board of Embrapa Soja as manuscript number 07/2007.

\section{REFERENCES}

Ávila, C. J. \& A. R. Panizzi. 1995. Occurrence and damage by Dichelops (Neodichelops) melacanthus (Dallas) (Heteroptera: Pentatomidae) on corn. Anais da Sociedade Entomológica do Brasil 24: 193194.

Chocorosqui, V. R. \& A. R. Panizzi. 2002. Influência da temperatura na biologia de ninfas de Dichelops melacanthus (Dallas, 1851) (Heteroptera: Pentatomidae). Semina 23: 217-220.

Chocorosqui, V. R. \& A. R. Panizzi. 2003. Photoperiod influence on the biology and phenological characteristics of Dichelops melacanthus (Dallas, 1851) (Heteroptera: Pentatomidae). Brazilian Journal of Biology 63: 655-664.

Chocorosqui, V. R. \& A. R. Panizzi. 2004. Impact of cultivation systems on Dichelops melacanthus (Dallas) (Heteroptera: Pentatomidae) populations and damage and its chemical control on wheat. Neotropical Entomology 33: 487-492.

Coombs, M. 2004. Broadleaf privet, Ligustrum lucidum Aiton (Oleaceae), a late-season host for Nezara viridula (L.), Plautia affinis Dallas and Glaucias amyoti (Dallas) (Hemiptera: Pentatomidae) in northern New South Wales, Australia. Australian Journal of Entomology 43: 335-339.

Fortes, P.; S. R. Magro; A. R. Panizzi \& J. R. P. Parra. 2006. Development of a dry artificial diet for Nezara viridula (L.) and Euschistus heros (Fabricius) (Heteroptera: Pentatomidae). Neotropical Entomology 35: 567-572.

Galileo, M. H. M.; H. A. O. Gastal \& J. Grazia. 1977. Levantamento populacional de Pentatomidae (Hemiptera) em cultura de soja (Glycine $\max$ (L.) Merr.) no município de Guaíba, Rio Grande do Sul. Revista Brasileira de Biologia 37: 111-120.

Gomez, S. A. 1998. Controle químico do percevejo Dichelops (Neodichelops) melacanthus (Dallas) (Heteroptera: Pentatomidae) na cultura do milho safrinha. Comunicado Técnico, Embrapa Dourados 44: 1-5.

Grazia, J. 1978. Revisão do gênero Dichelops Spinola, 1837 (Heteroptera, Pentatomidae, Pentatomini). Iheringia, Série Zoologia 53: 3-119.

Manfredi-Coimbra, S.; J. J. Silva; V. R. Chocorosqui \& A. R. Panizzi. 2005. Danos do percevejo barriga-verde Dichelops melacanthus (Dallas) (Heteroptera: Pentatomidae) em trigo. Ciência Rural 35: $1243-1247$.

Noda, T. \& S. Kamano. 1983. Effects of vitamins and aminoacids on the nymphal development of the bean bug, Riptortus clavatus Thunberg. Applied Entomology and Zoology 27: 295-299.

Panizzi, A. R. 2007. Nutritional ecology of plant feeding arthropods and IPM. In: M. Kogan \& P. C. Jepson (eds.). Perspectives in Ecological Theory and Integrated Pest Management. Cambridge University Press, Cambridge, UK pp 170-222.

Panizzi, A. R. \& R. M. L. Alves. 1993. Performance of nymphs and adults of the southern green stink bug (Heteroptera: Pentatomidae) exposed to soybean pods at different phenological stages of development. Journal of Economic Entomology 86: 1088-1093.

Panizzi, A. R. \& B. S. Corrêa-Ferreira. 1997. Dynamics in the insect fauna adaptation to soybean in the tropics. Trends in Entomology 1: 71-88.

Panizzi, A. R. \& A. P. M. Mourão. 1999. Mating, ovipositional rhythm and fecundity of Nezara viridula (L.) (Heteroptera: Pentatomidae) fed on privet, Ligustrum lucidum Thunb., and on soybean, Glycine $\max ($ L.) Merrill fruits. Anais da Sociedade Entomológica do Brasil 28: 35-40.

Panizzi, A. R.; J. R. P. Parra; C. H. Santos \& D. R. Carvalho. 2000. Rearing the southern green stink bug using an artificial diet and an artificial plant. Pesquisa Agropecuária Brasileira 35: 17091715.

Panizzi, A. R.; L. M. Vivan; B. S. Corrêa-Ferreira \& L. A. Foerster. 1996. Performance of southern green stink bug (Heteroptera: Pentatomidae) nymphs and adults on a novel food plant (Japanese privet) and other hosts. Annals of the Entomological Society of America 89: 822-827.

SAS Institute. 1981. SAS for linear models. A guide to the ANOVA and GLM procedures. SAS Institute, Cary, N.C.

Silva, F. A. C. \& A. R. Panizzi. 2007. Cotton balls as an oviposition substrate for laboratory rearing of phytophagous stink bugs (Heteroptera: Pentatomidae). Annals of the Entomological Society of America 100: 745-748.

Zar, J. H. 1984. Biostatistical analysis, 2nd ed., Prentice-Hall, Englewood Cliffs, N. J.

Received 27/02/2007; accepted 10/07/2007 